\title{
ORTODOKSI DAN HETERODOKSI NILAI-NILAI DI PESANTREN: STUDI KASUS PADA PERUBAHAN PERILAKU SANTRI DI ERA TEKNOLOGI DIGITAL
}

\author{
Akmal Mundiri ${ }^{1} \&$ Ira Nawiro $^{2}$ \\ 12Universitas Nurul Jadid, Probolinggo, Jawa Timur \\ 1akmalmundiri@gmail.com, 2nawiroh96@gmail.com
}

\begin{abstract}
Abstak
Perkembangan teknologi mempengaruhi hampir setiap lini kehidupan, termasuk kehidupan santri di pesantren. Penelitian ini bertujuan untuk mengungkap transformasi perilaku santri, ortodoksi dan heterodoksi, akibat dari perkembangan teknologi di dunia pesantren. Penelitian ini menggunakan pendekatan kualitatif dengan jenis studi kasus. Hasil penelitian menunjukkan beberapa perilaku ortodoksi yang sudah ada sejak dahulu masih terjaga di pesantren, seperti berpakaian sopan, mahir membaca kitab kuning bahkan memahami isinya, selalu mematuhi peraturan pesantren, menghormati yang lebih tua dan menyayangi yang lebih muda. Akan tetapi, terdapat pula perilaku yang menyimpang (heterodoksi) yang muncul akibat perkembangan zaman seperti imitasi budaya k-pop, minimnya kemampuan membaca kitab, melanggar tata tertib pesantren, bullying, transformasi otoritas keagamaan santri dan berubahnya sumber primer pembelajaran santri. Namun, terdapat beberapa perilaku yang tetap menjadi ciri khas pesantren seperti solidaritas, mandiri, ta'dzim terhadap kiai, juga mengelola pembelajaran sendiri.
\end{abstract}

Kata Kunci: Perilaku, Nilai-nilai Islami, Pesantren

\begin{abstract}
Technological developments affect almost every line of life, including the lives of santri in pesantren. This study aims to uncover the transformation of santri behavior, orthodoxy and heterodoxy, a result of technological developments in the pesantren world. This study uses a qualitative approach with a type of case study. The results showed that some of the orthodoxy behavior that had existed since long ago was still awake in Islamic boarding schools, such as dressing modestly, proficient at reading yellow books and even understanding its contents, always obeying the pesantren's rules, respecting the older and loving younger ones. However, there are also deviant behaviors (heterodoxy) that arise due to the current development, such as imitation of k-pop culture, lack of ability to read books, violating pesantren rules, bullying, transformation of santri religious authority and the change in primary learning sources of santri. However, there are several behaviors that remain the characteristics of pesantren such as solidarity, independence, ta'dzim towards kiai, and managing their own learning.

Keyword: Behaviour, Islamic values, Islamic boarding school.
\end{abstract}


Mundiri, A., \& Nawiro, I. (2019). ORTODOKSI DAN HETERODOKSI NILAI-NILAI DI PESANTREN: STUDI KASUS PADA PERUBAHAN PERILAKU SANTRI DI ERA TEKNOLOGI DIGITAL. Jurnal Tatsqif, 17(1), 1-18. https://doi.org/10.20414/ita.v17i1.527

\section{PENDAHULUAN}

Pesantren adalah sebuah lembaga pendidikan dan penyiaran agama Islam, tempat pelaksanaan kewajiban belajar dan mengajar serta pusat pengembangan masyarakat menjadi lebih baik yang diselenggarakan dalam kesatuan tempat pemukiman dengan masjid sebagai pusat pendidikan dan pembinaannya (Jamal, 2015). Selain itu ada pendapat yang menyatakan bahwasannya pesantren adalah lembaga pendidikan tradisional Islam untuk mempelajari, memahami, mendalami, menghayati, dan mengamalkan ajaran Islam dengan menekankan pentingnya moral keagamaan sebagai pedoman perilaku sehari-hari (Mastuhu, 1994).

Pondok pesantren yang melembaga di masyarakat, merupakan salah satu lembaga pendidikan Islam tertua di Indonesia. Eksistensinya sudah teruji oleh zaman, sehingga sampai saat ini pesantren masih tetap hidup walau dengan berbagai terpaan transformasi zaman (Zulhimma, 2013). Pesantren adalah suatu bentuk lingkungan masyarakat yang unik dan memiliki tata nilai kehidupan yang positif dan mempunyai ciri khas tersendiri seperti: 1) adanya hubungan yang akrab antara santri dan kiai, 2) santri ta'dzim terhadap kiainya, 3) semua santri hidup secara sederhana dan mandiri, 4) semangat gotong royong dengan penuh persaudaraan, 5) para santri terlatih hidup disiplin dan terikat, terutama dalam sistem pendidikannya yang mengadopsi sistem pendidikan dua puluh empat jam, dengan mengkondisikan para santri dalam satu lokasi sebuah asrama, hal ini yang menjadikan pesantren lembaga yang bermutu dan terjamin (Akmal Mundiri \& Afidatul Bariroh, 2018).

Selain itu kegiatan santri juga dikontrol melalui peraturan atau tata tertib yang sudah ditetapkan dalam sebuah pesantren demi terwujudnya santri yang selalu membiasakan berperilaku mulia, seperti dalam kesehariannya seorang santri dituntut hidup mandiri dan disiplin. Santri itu mandiri dalam berbagai hal, dari memanagemen uang kiriman, bangun pagi, mencuci pakaian, menguras kamar mandi, menyapu kamar atau halaman 
Mundiri, A., \& Nawiro, I. (2019). ORTODOKSI DAN HETERODOKSI NILAI-NILAI DI PESANTREN: STUDI KASUS PADA PERUBAHAN PERILAKU SANTRI DI ERA TEKNOLOGI DIGITAL. Jurnal Tatsqif, 17(1), 1-18. https://doi.org/10.20414/ita.v17i1.527

asrama hingga belajar semua dilakukan sendiri, namun kata sendiri bisa saja dilakukan secara beramai-ramai atau bergotong royong seperti halnya membersihkan lingkungan pesantren. Disiplin di pesantren dapat diartikan mentaati dan mematuhi peraturan, seperti saat kembali ke pesantren tepat pada waktunya, jam istirahat santri, berangkat sekolah semuanya memiliki aturan yang harus dipatuhi dan perlu kedisiplinan dalam menjalankannya.

Peraturan yang telah di buat oleh pesantren tidak sepenuhnya dapat menjadikan semua santri berperilaku baik, terdapat beberapa faktor yang menyebabkan perilaku santri bermasalah walaupun telah ditetapkan sanksi bagi pelanggar peraturan. Perilaku santri yang bermasalah bisa dicontohkan seperti tidak melakukan sholat berjama'ah di masjid bersama kiai, ghasab (meminjam, mengambil, bahkan memiliki) barang temannya tanpa izin, tidak mengikuti kegiatan pesantren yang sudah terjadwal, merokok, bolos sekolah, mem-bully temannya, berpacaran dan banyak lainnya perilaku yang menyalahi aturan pesantren. Perilaku-perilaku yang bermasalah biasanya dilakukan oleh santri karena mereka ingin mencari perhatian, kurang mampu mengelola emosi, atau karena ingin membela diri atas keadaan lingkungan yang membuat dirinya merasakan tidak nyaman (Netrasari, 2015).

Dinamika perkembangan teknologi juga secara tidak langsung dan secara gradual berdampak terhadap perilaku santri. Namun di sisi lain, pesantren mau tidak mau harus melakukan akomodasi terhadap perkembangan teknologi. Pesantren akan tetap eksis dan berkembang jika sebuah pesantren dapat mengkolaborasikan nilai-nilai budaya modern tanpa mengenyampingkan nilai-nilai budaya klasik, karena untuk zaman sekarang harus melihat kebutuhan santri, jika tetap menganut ajaran resmi terdahulu tanpa memasukkan unsur-unsur teknologi yang berkembang bisa jadi banyak santri yang keluar dan lebih memilih lembaga pendidikan yang lain.

Perkembangan teknologi dapat dimanfaatkan dalam berbagai bidang, seperti dalam bidang informasi yang saat ini di lembaga pendidikan 
sudah tidak menggunakan sistem tempel informasi yang biasa diletakkan di mading, akan tetapi sudah menggunakan telegram dan semacamnya. Selain itu, bukan hanya siswa dari lembaga non pesantren yang memanfaatkan google sebagai bahan-bahan refrensi dalam menambah keilmuannya, juga santri yang bermukim di pesantren melakukan hal yang serupa. Dengan demikian santri generasi saat ini bisa dikatakan generasi Y. (Saputra, 2016).

Santri millenial dihadapkan pada teknologi internet yang menjadi dua mata pisau dalam menggunakannya. Internet akan menjadi hiburan semu duniawi yang bersifat merusak jika tidak memahami cara memanfaatkannya. Tetapi disisi lain internet juga dapat dimanfaatkan sebagai sarana untuk belajar, bisnis maupun Dakwah.

Berdasarkan uraian sebagaimana di atas, maka penelitian ini berupaya mengungkap tentang dampak teknologi digital terhadap perilaku santri, yaitu ditinjau dari perilaku ortodoksi dan heterodoksi pada santri di pesantren.

\section{LANDASAN TEORI}

Secara etimologis ortodoksi berarti ajaran yang benar; heterodoksi berarti ajaran yang seperti benar padahal tidak. Secara terminologis ortodoksi berarti ketaatan kepada ajaran resmi, sedangkan heterodoksi berarti penyimpangan dari ajaran resmi. Arkoun menjelaskan ortodoksi merupakan ajaran yang menjadi kesadaran kelompok mayoritas yang dengannya kelompok itu melihat berbagai kesadaran lain yang dikembangkan oleh kelompok minoritas yang berupa penyimpangan sebagai heterodoksi (Dernawan, 2012).

Nilai-nilai pesantren biasanya didasarkan pada pokok-pokok ajaran al-Qur'an dan al-Hadits. Adapun nilai-nilai tersebut terangkum menjadi tiga, yakni 1) Nilai Aqidah, nilai yang berupa beberapa perkara yang wajib bagi manusia diyakini kebenarannya oleh hati, mendatangkan ketentraman jiwa, menjadi keyakinan yang tidak bercampur sedikitpun dengan keraguan 
Mundiri, A., \& Nawiro, I. (2019). ORTODOKSI DAN HETERODOKSI NILAI-NILAI DI PESANTREN: STUDI KASUS PADA PERUBAHAN PERILAKU SANTRI DI ERA TEKNOLOGI DIGITAL. Jurnal Tatsqif, 17(1), 1-18. https://doi.org/10.20414/ita.v17i1.527

seperti percaya kepada Allah, 2) Nilai Ibadah, nilai ibadah merupakan nilai yang mencakup segala perbuatan yang disukai dan diridhai oleh Allah SWT, baik berupa perkataan maupun perbuatan, baik terangterangan maupun tersembunyi dalam rangka mengagungkan Allah SWT dan mengharapkan pahalaNya, dan 3) Nilai Akhlaq, nilai akhlak merupakan segala hal yang berkaitan dengan sifat yang yang tertanam dalam jiwa manusia yang muncul dengan sendirinya tanpa melalui pemikiran maupun pertimbangan, serta tidak ada dorongan dari luar (Ramdhani, 2015).

\section{METODE}

Penelitian ini menggunakan pendekatan yang berangkat dari paradigma interpretif yang mempunyai fokus makna dibalik suatu tindakan. Penelitian ini berjenis studi kasus (case study), yang dalam hal ini peneliti berupaya menyelidiki fenomena dalam konteks kehidupan nyata dengan memanfaatkan multi sumber yang ada dalam kehidupan manusia (Yin, 2003). Salah satu keunikan dalam penelitian kualitatif adalah peneliti bertindak sebagai instrumen utama (the instrument of choice in naturalistic inquiry is the human) sekaligus pengumpul data.

Sedangkan data dalam penelitian ini berupa kata-kata, perilaku, dokumen dan lain-lain tentang perubahan perilaku santri di era milenial, yang di dapat dengan menggunakan teknik pengumpulan data observasi, wawancara, dan dokumentasi. Dengan demikian, maka informan dalam penelitian ini adalah para santri milenial dan pengurus pondok pesantren yang dipilih berdasarkan teknik purposive dan dilanjutkan dengan teknik snowball. Peneliti memetakan jenis data penelitian dalam penelitian ini berdasarkan kegunaannya menjadi data primer dan data sekunder. Data primer diperoleh dalam bentuk perilaku dan ucapan dari subjek (informan) berkaitan dengan perubahan perilaku santri di era digital. Sedangkan data sekunder bersumber dari dokumen-dokumen, foto-foto, dan benda lainnya yang dapat digunakan sebagai pelengkap atau pendukung data primer. 
Mundiri, A., \& Nawiro, I. (2019). ORTODOKSI DAN HETERODOKSI NILAI-NILAI DI PESANTREN: STUDI KASUS PADA PERUBAHAN PERILAKU SANTRI DI ERA TEKNOLOGI DIGITAL. Jurnal Tatsqif, 17(1), 1-18. https://doi.org/10.20414/itq.v17i1.527

Dalam menganalisis, peneliti melakukan interpretasi terhadap data sehingga diperoleh makna (meaning). Analisis dilakukan selama pengumpulan data di lapangan dan setelah data itu terkumpul. (Sudarsono, 1992) Hal tersebut senada dengan pernyataan Milles dan Huberman bahwa analisis data dalam penelitian kualitatif dapat dilakukan baik selama proses pengumpulan data maupun setelah pengumpulan data melalui tahapan analisis reduksi data, penyajian data, dan penarikan kesimpulan atau verifikasi. Untuk melakukan pengecekan keabsahan data, peneliti menggunakan teknik perpanjangan keikutsertaan, ketekunan pengamatan, dan triangulasi.

\section{HASIL DAN PEMBAHASAN}

Transformasi atau perubahan perilaku santri dalam hal ini adalah berubahnya atau beralihnya kegiatan para santri baik yang diamati secara langsung ataupun tidak. Pengertian perubahan disini menuju kepada perubahan ke arah negatif (M.Muzakki, Happy Santoso, 2016). Penyebab perubahan perilaku santri yang awalnya andab ashor dan sekarang marak dekadensi moral dikarenakan sisi negatif budaya asing yang masuk ke lingkungan pesantren.

Bentuk-bentuk perilaku santri zaman dulu dan santri saat ini terlihat berbeda, pasalnya perilaku santri sekarang rentan berubah-ubah karena dipengaruhi keadaan lingkungan yang tidak mendukung dan membawa pengaruh kurang baik (M.Muzakki, Happy Santoso, 2016). Akan tetapi, tidak semua hegemoni budaya dapat memperburuk keadaan, namun jika hegemoni dijadikan stimulus yang kemudian dibekali dengan nilai-nilai pesantren maka akan terjadi perubahan perilaku ke arah yang lebih baik. Bentuk-bentuk transformasi habitus santri yaitu:

1. Imitasi Budaya K-Pop

Imitasi atau tiruan yang diperkenalkan oleh Miller dan Dollard ini merupakan cara terpenting dari proses belajar sosial (social learning), di mana seseorang mempelajari perannya dan peran 
orang lain di dalam kehidupan bermasyarakat. Dalam proses imitasi ini, seseorang akan belajar untuk dapat menyesuaikan tingkah lakunya sesuai dengan peran sosial yang telah dipelajarinya (Sarwono, 1983). Imitasi yang sedang popular saat ini adalah imitasi budaya k-Pop (Korean Pop) yang banyak dipengaruhi oleh korea selatan dan biasa disebut dengan korean wave atau hallyu.

Korean wave merupakan fenomena yang muncul karena adanya era globalisasi yang membawa produk-produk budaya popular dari Negara Korea Selatan, seperti musik, drama, fashion, juga make-up (Ridaryanthi, 2014). Perlahan tapi pasti, budaya lokal mulai tergeser oleh budaya pop Korea. Santri yang kebanyakan remaja lebih memilih meniru budaya popular Korea ketimbang budaya lokal. Sehingga terjadi ketimpangan antara budaya lokal yakni budaya Indonesia dan budaya populer Korea. Salah satunya yang terjadi di pesantren, bukan hanya mengagumi budaya popular Korea saja namun juga mengadopsinya ke dalam kehidupan dan perilaku.

Masyarakat begitu juga dengan santri mengadopsi budaya kpop bukan karena kebutuhan melainkan karena keinginan meniru budaya tersebut, yang mana tidak semua budaya k-pop itu memberikan suatu hal yang positif akan tetapi banyak sisi negatif dari budaya k-pop itu sendiri. Produk budaya k-pop seperti musik yang disertai dengan dance khas korea kini telah banyak ditiru oleh kalangan santri di pesantren, bahkan hal ini dijadikan sebagai ajang perlombaan ketika pesantren memperingati hari besar Islam. Tidak ada yang salah dalam hal ini, namun pemandangan yang sedemikian rupa seharusnya tidak muncul di pesantren, karena pesantren mengajarkan seseorang untuk berakhlak dan meneladani Rasulullah bukan artis korea. Selain itu, imitasi seperti ini dapat berimbas kepada perilaku santri yang akan membawa ke arah negatif, seperti cara berpakaian yang tidak sepenuhnya menutup aurat dan lekuk tubuh karena meniru artis korea dan banyk contoh lainnya. 


\section{Minimnya Kemampuan Membaca Kitab Kuning}

Kemampuan membaca kitab kuning merupakan sesuatu yang fundamental bagi seorang santri, dahulu santri yang lancer membaca kitab kuning beserta artinya merupakan hal yang wajar dan sudah menjadi kekhasan seorang santri, namun saat ini hal tersebut menjadi langka akibat lingkungan yang tidak baik dan berkurangnya ke-ajeg-an dari santri itu sendiri untuk terus belajar sehingga mampu dalam membaca kitab kuning bahkan fashih membaca al-Qur'an. Padahal kitab kuning merupakan salah satu unsur mutlak dari proses belajar mengajar di pesantren. Kitab kuning sangat penting dalam membentuk kecerdasan intelektual dan moralitas kesalehan (kualitas beragama) pada diri santri (Yafie, 1994). Selain itu tujuan utama ada pengajaran kitab kuning adalah untuk mendidik caloncalon ulama' generasi penerus (Dhofier, 2011). Sedangkan pada kenyataannya, saat ini kurang memahami bahkan tidak bisa membaca kitab kuning, dan lebih memilih skill yang lainnya.

3. Melanggar tata tertib pesantren

Santri zaman dulu sangat ketakutan apabila melakukan pelanggran di pesantren, seperti halnya tidak melaksanakan sholat berjama'ah di masjid, mencuri, ataupun bolos sekolah, santri beranggapan bahwa melakukan pelanggaran sama halnya dengan menjadikan dirinya sia-sia dalam menuntut ilmu di pesantren karena ilmu yang didapat tidak akan bermanfa'at. Berbeda dengan santri sekarang yang meremehkan peraturan dan kegiatan pesantren yang terjadwal sehingga kurang mematuhi tata tertib pesantren.

Tata tertib merupakan salah satu tindakan preventif pada santri agar tidak melakukan tindakan di luar batas (Ma'arif, 2018). Meskipun tata tertib pesantren sudah ada dan memiliki sanksi tiap peraturan yang tertera, akan tetapi tidak sedikit dari beberapa santri melakukan tindakan buruk dengan melanggar tata tertib tersebut. Oleh 
sebab itu dibutuhkan hukuman represif agar peserta didik ini tidak mengulangi kesalahan yang sama.

Pesantren akan menyesuaikan hukuman yang diberikan kepada santri tergantung pada pelanggaran yang dilakukan. Ada berbagai macam cara pemberian hukuman kepada santri (W, 2015), yaitu bisa dengan teguran atau nasihat, cara itu dipakai bagi santri yang baru pertama kali melakukan pelanggaran dan pelanggaran yang dilakukan merupakan pelanggaran ringan. Berikutnya dengan cara hukuman yang mendidik dan hukuman administrasi. Hukuman ini dilakukan bila teguran dan nasihat tidak membuat perilaku santri baik, maka bagi pelanggar akan dilaksanakan hukuman mendidik yakni semisal membaca al-Qur'an tiga juz sambil berdiri, atau menulis istighfar sebanyak seribu, sedangkan hukuman administrasi yakni pelaporan kepada wali santri tentang pelanggaran yang dilakukan putra-putrinya.

Hukuman bersifat sosial diberikan kepada santri yang melakukan pelanggaran sedang seperti sering bolos sekolah, keluar pesantren tanpa izin dari pengurus atau pengasuh, juga merokok di area pesantren, biasanya hukumannya berupa bersih-bersih halam pesantren, menyikat kamar mandi dan hal-hal yang berhubungan dengan kebersihan. Hukuman berupa materi juga dapat dijadikan hukuman yang efektif bagi santri yang telat kembali ke pesntren dengan meminta sumbangan berupa uang atau semen untuk pesantren, hal ini dapat memberikan efek jera bagi para santri. Hukuman yang terakhir yaitu hukuman fisik, biasanya hukuman ini diterapkan bagi santri yang melakukan pelanggaran berat, namun hukuman fisik saat ini sudah banyak dihapus akibat pengaruh buruk yang muncul ketika hukuman fisik itu diterapkan.

Peraturan atau tata tertib yang positif dapat membentuk karakter baik seorang santri. Tentunya kepatuhan terhadap kiai, tata tertib dan kemandirian menjadi aspek psikologis yang sangat lekat dengan kehidupan santri di pesantren. Secara teoretik, kepatuhan pada 
taraf tertentu dapat menghambat perkembangan kemandirian seseorang karena kepatuhan menuntut seseorang untuk mengikuti saja perintah atau permintaan orang lain (Syarif, 2012). Kepatuhan adalah perubahan sikap dan tingkah laku seseorang untuk mengikuti perintah orang lain. Namun kepatuhan yang diterapkan di pesantren tidak menghambat kemandirian santri, bahkan dengan kepatuhan mengajarkan sikap kedisiplinan. Hal itu dikarenakan semua tata tertib yang dibuat pesantren bersifat positif dan bertujuan untuk mengubah perilaku ke arah yang lebih baik.

\section{Bullying}

Indahnya ketika melihat kaum santri yang saling mengasihi dan menyayangi satu sama lain, tidak memilih-milih teman, membantu saat teman yang lain dalam kesulitan dan banyak contoh lainnya. Namun, adat seperti itu kini kurang ter-ekspose di masyarakat, bahkan saat ini yang banyak terdengar oleh telinga masyarakat bahwasannya pesantren mulai marak perilaku bullying.

Penindasan atau yang terkenal dengan istilah bullying saat ini telah menjadi hal yang biasa ada di pesantren, yang lebih tua yang berkuasa dan yang muda yang mendapat perilaku bully tersebut. Mengejek dan mengolok teman satu asrama merupakan perilaku-perilaku yang dilakukan para santri untuk membuat temannya merasakan ketidaknyamanan berada di asrama tersebut kemudian menguasai asrama itu, dan hal yang membuat perlakuan bully tetap ada di pesantren adalah yang lebih tua atau santri kelas akhir yang memiliki hak lebih untuk mengatur santri baru. Bukan orang yang lebih memahami atau berpengalaman dalam hal mendidik dan membimbing yang dijadikan sebagai tutor atau pengurus di asrama.

5. Transformasi Otoritas Keagamaan Santri

Otoritas merupakan wewenang untuk bertindak, memimpin dan memutuskan (Khotim, 2018). Individu yang memiliki kemampuan secara intelektualitas dalam bidang agama seperti halnya santri, dapat 
menyandang status sebagai otoritas religius, yang mana di persyaratkan untuk mendapatkan pengakuan dari pihak lain atau masyarakat (Abdul, 2014). Seperti santri dahulu memiliki otoritas penuh dalam bidang keagamaan karena ilmunya yang didapat selama di pesantren dan diakui oleh masyarakat sekitar.

Santri antri zaman now tidak menjadikan kitab kuning sebagai satu-satunya rujukan bidang keilmuan, padahal kitab kuning merupakan rujukan dasar untuk segala keilmuan agama Islam yang mengupas tentang apa yang ada dalam al-Qur'an dan al-Hadits. Sedangkan santri saat ini juga telah menjadikan internet sebagai sumber refrensi keilmuan agama karena sangat mudah diakses di mana pun dan kapan pun. Hal ini menjadikan santri kurang memahami kitab kuning dan akan berimbas pada otoritatif santri dalam menjawab pertanyaan-pertanyaan masyarakat seputar agama. Keberadaan santri tidak akan dianggap lagi sebagai seorang yang paham agama, padahal sejak dahulu santri merupakan sosok orang alim yang sangat mahir membaca kitab dan sangat memahami isi kitab bahkan hafal. Oleh karena itu, merupakan hal yang wajar jika masyarakat menganggap santri adalah orang yang otoritatif dalam hal keagamaan.

6. Berubahnya Sumber Primer Pembelajaran Santri

Pesantren dahulu telah menjadikan kitab kuning sebagai sumber primer santri, namun saat ini sumber primer itu telah berubah menjadi sumber sekunder yang disebabkan oleh internet. Internet memang telah menjadi salah satu penanda utama munculnya generasi milenial, tak terkecuali di kalangan santri saat ini. Perkembangannya yang sedemikian cepat telah membuat siapapun tidak kuasa menolak kehadirannya dan karenanya perubahan-perubahan banyak terjadi seperti yang dialami oleh santri seperti dalam sumber belajarnya.

Julukan santri bagi seseorang merupakan hal yang berat dikarenakan santri saat ini harus menghadapi berbagai gelombang 
perubahan mode komunikasi dan sumber belajar santri itu sendiri. Kultur pesantren menuntut santri untuk mendalami ilmu-ilmu agama dahulu baru boleh meninggalkan pesantren, sementara kultur masyarakat menuntut santri untuk cepat memberi solusi dari isu-isu yang muncul dan marak di internet karena kebanyakan kajian keislaman yang ada di internet, kini didominasi oleh kelompok Islam radikal yang bercorak ekstrem dan fundamentalis. Hal semacam ini yang menjadikan santri bingung dalam menghadapinya dan pada akhirnya santri sering telat menanggapi isu-isu yang tidak berbobot di internet.

Selain itu, hal yang menjadikan berubahnya sumber belajar santri dari kitab kuning ke internet adalah mudahnya mengakses internet di mana pun dan kapan pun tanpa dibatasi ruang dan waktu, juga dengan berbagai macam kajian keislaman yang ditawarkan oleh internet yang dapat memenuhi persoalan dan kebutuhan masyarakat seputar keagamaan walaupun refrensinya tidak jelas dari kitab atau ulama' mana.

Pergeseran nilai dan perilaku yang dialami santri tidak menjamah atau mencabut nilai-nilai mendasar yang dimiliki santri yang sampai saat ini masih menjadi ciri khas santri yakni seperti kemandirian, self directered learning, solidaritas dalam hubungan pertemanan, juga ta'dzim dan komitmen afektif tehadap kiai.

Proses transformasi sosial budaya yang semakin cepat, pergeseran nilai nilai pesantren akibat sistem kapitalisme mulai tercabut dari akar budaya klasik pesantren, yang terilhami oleh pergaulan bebas dari dunia barat yang sangat sekuler dan merusak. Nilai-nilai pesantren tersebut akan menjadi tanggung jawab berat institusi pendidikan Islam di pesantren untuk menata kembali nilai-nilai pesantren yang sudah berada pada titik nadir.

Arkoun menjelaskan ortodoksi merupakan ajaran yang menjadi kesadaran kelompok mayoritas yang dengannya kelompok itu melihat berbagai kesadaran lain yang dikembangkan oleh kelompok minoritas yang berupa penyimpangan sebagai heterodoksi (Dernawan, 2012). Dari 
Mundiri, A., \& Nawiro, I. (2019). ORTODOKSI DAN HETERODOKSI NILAI-NILAI DI PESANTREN: STUDI KASUS PADA PERUBAHAN PERILAKU SANTRI DI ERA TEKNOLOGI DIGITAL. Jurnal Tatsqif, 17(1), 1-18. https://doi.org/10.20414/ita.v17i1.527

pengertian yang Arkoun jelaskan disini dapat ditinjau bahwasannya perilaku ortodoksi bisa dikatakan sebagai perilaku-perilaku mulia yang mengikuti perilaku Rasulullah pada zaman dahulu. Perilaku atau perbuatan Rasulullah sudah banyak dijelaskan di dalam al-Qur'an, al-Hadits dan juga beberapa kitab-kitab klasik yang di dalamnya menerangkan tentang fi'liyah-fi'liyah Rasulullah SAW, maka tinggal santri itu sendiri dapat menirukan dan mengamalkannya dalam kehidupan sehari-hari atau tidak. Sedangkan perilaku heterodoksi merupakan penyimpangan dari perilaku-perilku ortodoksi tersebut, kemungkinan besar hal ini terjadi dikarenakan efek globalisasi yang menjadi boomerang bagi santri khususnya santri di era milenial saat ini.

Generasi milenial dikenal dengan generasi yang kreatif salah satu faktor pendukungnya adalah teknologi, dan santri milenial yang saat ini berada di pesantren atau bahkan yang sudah terjun kemasyarakat banyak menggunakan internet dan media sosial untuk mendukung pekerjaan. Karena media sosial baru diperkenalkan pada saat sebagian besar generasi ini sudah bekerja, maka santri sebagai generasi milenial memanfaatkan sarana itu bukan untuk kebutuhan eksistensi diri, tetapi untuk mendukung pekerjaan (Khozin, 2018). Santri milenial santri yang canggih teknologi, berdakwah lewat media sosial, santri anti-Hoax atau sadar akan isu, banyak memiliki peluang usaha, dan lebih berpendidikan (Khozin, 2018).

Pesantren manapun sangat kaku terhadap aturan pemakaian smartphone dan gadget. Teknologi super canggih ini peredarannya sangat ketat diawasi selama seseorang berada di dalam pondok pesantren meskipun sebenarnya para santri itu mampu untuk membelinya. Ketika santri lulus dari pesantren kemudian terjun dan berbaur pada masyarakat, semua kecanggihan teknologi yang ditawarkan dunia boleh dikuasai namun dengan tetap memikul nama baik sebagai seorang santri, dengan kata lain tidak menyalahgunakan teknologi tersebut. Setelah itu santri dapat melanjutkan 
Mundiri, A., \& Nawiro, I. (2019). ORTODOKSI DAN HETERODOKSI NILAI-NILAI DI PESANTREN: STUDI KASUS PADA PERUBAHAN PERILAKU SANTRI DI ERA TEKNOLOGI DIGITAL. Jurnal Tatsqif, 17(1), 1-18. https://doi.org/10.20414/ita.v17i1.527

tugasnya di luar pesantren dengan mengoptimalkan pemakaian gadget dan memanfaatkan kecanggihan teknologi.

Gadget bisa dipakai untuk keperluan apapun, termasuk membuat akun media sosial yang kemudian dimanfaatkan untuk berdakwah ataupun menambah wawasan, karena walaupun santri sudah keluar dari tembok pesantren, tetap wajib menyerap ilmu setiap hari dari siapapun. Sebab pada dasarnya, ilmu itu berkembang dan inspirasi baru bermekaran setiap hari.

Berdakwah lewat media sosial juga saat ini sudah banyak dilakukan oleh para santri. Dulu, para guru agama atau ustadz berdakwah secara door to door, dari musholla satu ke musholla lainnya atau dari forum satu ke forum lainnya. Tapi sekarang seorang ustadz yang ingin berdakwah tinggal duduk manis dan stand by dengan kamera handphone-nya yang kemudian dalam waktu sekejap bisa langsung siaran live di facebook atau di media sosial lainnya. Selain caranya yang mudah dan sederhana juga hal ini dapat memberikan manfaat seluas-luasnya untuk banyak orang.

Isu-isu murah yang berharga mahal itu (Hoax) kini telah hadir di masyarakat dan menjamur di media sosial seperti isu politik, ekonomi, hukum, alam dan banyak lainnya. Pemahaman hoax disini adalah informasi menyimpang dari fakta yang masih dapat diteliti dengan menggunakan pikiran. oleh karena itu, hoax dapat diberantas oleh akal sehat. Selain itu, sadar dan melek terhadap perkembangan ilmu pengetahuan dan teknologi merupakan hal yang dapat membuat seseorang terhindar dari hoax. Bekal ilmu dari pesantren pun menjadikan santri anti-Hoax dan membantu orang lain untuk terhindar dari hoax tersebut. Seperti ayat al-Qur'an dalam surat alHujurat ayat 6 yang menjelaskan untuk selalu berhati-hati pada berita yang datang, yaitu yang artinya: "Hai orang-orang yang beriman, jika datang kepadamu orang fasik membawa suatu berita, Maka periksalah dengan teliti agar kamu tidak menimpakan suatu musibah kepada suatu kaum tanpa mengetahui keadaannya yang menyebabkan kamu menyesal atas perbuatanmu itu (QS Al Hujurat Ayat 6)." 
Mundiri, A., \& Nawiro, I. (2019). ORTODOKSI DAN HETERODOKSI NILAI-NILAI DI PESANTREN: STUDI KASUS PADA PERUBAHAN PERILAKU SANTRI DI ERA TEKNOLOGI DIGITAL. Jurnal Tatsqif, 17(1), 1-18. https://doi.org/10.20414/ita.v17i1.527

Kini saatnya para santri yang sudah berada di masyarakat bahkan telah menjadi tokoh masyarakat untuk menyuarakan kebenaran dan nilainilai Islam yang sejuk, anti kebohongan dan pembodohan secara teratur dengan memanfaatkan teknologi yang ada serta menggunakan bahkan mengajarkan teknologi tersebut dengan sebaik mungkin.

Santri milenial biasanya setelah lulus dari pesantren akan membuka ladang usaha bagi dirinya sendiri dan orang lain, karena generasi ini lebih menyenangi menggeluti pekerjaan yang di rintis sendiri daripada menjadi seorang pegawai. Santri dianggap memiliki potensi yang cukup produktif untuk dikembangkan dalam dunia kewirausahaan karena secara tidak sadar para santri telah dididik oleh pesantren dengan nilai kemandirian tersebut.

Dikatakan sebagai generasi yang lebih berpendidikan karena santri pada generasi ini dapat mengenyam pendidikan lebih tenang daripada santri yang menuntut ilmu saat masa-masa penjajahan, selain itu, santri generasi ini juga dapat menimba ilmu dan menambah wawasannya di mana saja dan kapan saja dengan kecanggihan teknologi yang sekarang sudah ada. Namun, untuk seorang santri alangkah baiknya jika mereka menuntut ilmu langsung kepada sang kiai agar mendapat barakah dari Allah lewat kiai tersebut, begitulah keyakinan masyarakat.

\section{KESIMPULAN}

Dari pembahasan di atas dapat ditarik kesimpulan bahwa perilaku santri zaman dahulu dan sekarang mengalami transformasi. Transformasi yang paling menonjol adalah transformasi habitus santri dan dari transformasi akibat globalisasi menimbulkan perilaku-perilaku yang tidak sesuai dengan nilai-nilai pesantren yang sudah ada sejak dahulu. Adapun bentuk-bentuk transformasi habitus santri yaitu berupa imitasi budaya kpop, minimnya kemampuan santri dalam membaca kitab kuning, banyaknya santri yang melanggar tata tertib pesantren, bullying, transformasi pada otoritas keagamaan santri dan berubahnya sumber primer pembelajaran santri. Namun dengan adanya bentuk-bentuk transformasi habitus santri, 
Mundiri, A., \& Nawiro, I. (2019). ORTODOKSI DAN HETERODOKSI NILAI-NILAI DI PESANTREN: STUDI KASUS PADA PERUBAHAN PERILAKU SANTRI DI ERA TEKNOLOGI DIGITAL. Jurnal Tatsqif, 17(1), 1-18. https://doi.org/10.20414/ita.v17i1.527

masih ada habitus-habitus santri yang sampai saat ini menjadi ciri khas di pesantren seperti mandiri, self derectered learning, solidaritas, dan ta'dzim. Perilaku santri tinjauan ortodoksi selayaknya perilaku santri zaman dahulu yang masih melekat dengan nilai-nilai pesantren, sedangkan perilaku santri milenial tinjauan heterodoksi merupakan perilaku santri zaman now yang menyimpang dari norma dan nilai-nilai pesantren. Namun tidak berarti milenial adalah suatu hal yang buruk, jika seorang santri milenial atau santri serba teknologi ini bisa memanfaatkan teknologi tersebut sebaik mungkin, hal-hal yang buruk tidak akan pernah ada, akan tetapi kemajuan bangsa Indonesia akan semakin berkembang dengan adanya santri milenial yang tetap menerapkan nilai-nilai pesantren dan mengikuti perkembangan zaman yang ada.

\section{DAFTAR PUSTAKA}

Abdul, S. G. (2014). Peran Ulama dalam Legislasi Modern Hukum Islam, AsySyari'ah. Ilmuu Syari'ah dan Hukum, 49(01).

Akmal Mundiri \& Afidatul Bariroh. (2018). Trans Internalisasi Pembentukan Karakter Melalui Trilogi dan Panca Kesandaran Santri. IQRA', 3(1).

Akmal Mundiri, Afidatul Bariroh. (2018, Juni). Trans Internalisasi Pembentukan Karakter Melalui Trilogi Santri dan Panca Kesandaran Santri. IQRA` (Jurnal Kajian Ilmu Pendidikan), 3(1), 29.

Darmoko, Muammar Ramadhan \& Puji Dwi. (2015). Penndidikan Pesantren dan NIlai BUdaya Damai. Madaniyah.

Dernawan, D. (2012). Ortodoksi dan Heterodoksi Tafsir. Refleksi, 13(2).

Dhofier, Z. (2011). Tradisi Pesantren: Studi Pandangan Hidup Kyai dan Visinya Mengenai Masa Depan Indonesia. Jakarta: LP3ES.

Hasbullah. (1999). Sejarah Pendidikan Islam di Indonesia. Jakarta: LKIS.

Herman. (2013). Sejarah Pesantren di Indonesia. $A l$ Ta'dib, 6(2).

Jamal, N. (2015). Transformasi Pendidikan Pesantren dalam Pembentukan Kepribadian Santri. Tarbiyatuna, 8(2). 
Mundiri, A., \& Nawiro, I. (2019). ORTODOKSI DAN HETERODOKSI NILAI-NILAI DI PESANTREN: STUDI KASUS PADA PERUBAHAN PERILAKU SANTRI DI ERA TEKNOLOGI DIGITAL. Jurnal Tatsqif, 17(1), 1-18. https://doi.org/10.20414/ita.v17i1.527

Khotim, A. (2018). Otoritas Keagamaan dan Fatwa Personal di Indonesia. Episteme, 13(01).

Khozin, M. (2018). Santri Milenial. Jakarta: Bhuana Ilmu Populer Kelompok Gramedia.

Lanny Octavia dkk. (2004). Pendidikan Karakter Berbasis Tradisi Pesantren. Jakarta: Rumah Kitab.

M.Muzakki, Happy Santoso. (2016). Peubahan Perilaku Santri (Studi Kasus Alumni Pondok Pesantren Salafiyah di Desa Langkap Kecamatan Besuki Kabupaten Situbondo). Istawa, 02(01).

Ma'arif, M. A. (2018). Fenomenologi Hukuman di Pesantren; Analsis Tata Tertib Santri Pondok Pesantren Daruttaqwa Gresik. Nadwa, 12(01).

Mahfud. (2014). Transformasi Pendidikan Pondok Pesantren Hasan Jufri Singkapura Bawean. Gresikdidaktika Religia, 2(1).

Mastuhu. (1994). Dinamika Sistem Pendidikan Pesantren. Jakarta: INIS.

Nawawi. (2006). Sejarah dan Perkembangan Pesantren. $I b d a^{\prime}, 4(1)$.

Netrasari, E. E. (2015). Studi Kasus Perilaku Agresif Remaja di Pondok Pesantren. Bimbingan dan Konseling.

Ramdhani, D. (2015). Penanaman Nilai-Nilai Keislaman dalam Pendidikan Agama Islam di Pondok Pesantren Darusy Syahadah Simo Boyolali Tahun Pelajaran 2015/2016. Surakarta: Universitas Muhammadiyah.

Ridaryanthi, M. (2014). Bentuk Budaya Populer dan Kontruksi Perilaku Konsumen Studi terhadap Remaja. Visi Komunikasi, 13(01).

Saputra, Y. (2016). Theoritical Review; Teori Perbedaan Generasi. Among Makarti, 9(18).

Sarwono, S. W. (1983). Teori-teori Psikologi Sosial. Jakarta: Balai Pustaka.

Siswati, E. (2007). Anatomi Teori Hegemoni Antonio Gramsci. Transliterasi.

Siti Ma'rifah \& M. Mustaqim. (2015). Pesantren sebagai Habitus Peradaban Islam Indonesia. Penelitian, 347-366.

Syafe'i, I. (2017). Pondok Pesantren: Lembaga Pendidikan Karakter. Tadzkiyyah, 8. 
Mundiri, A., \& Nawiro, I. (2019). ORTODOKSI DAN HETERODOKSI NILAI-NILAI DI PESANTREN: STUDI KASUS PADA PERUBAHAN PERILAKU SANTRI DI ERA TEKNOLOGI DIGITAL. Jurnal Tatsqif, 17(1), 1-18. https://doi.org/10.20414/ita.v17i1.527

Syarif, Z. (2012). Mitos Nilai-Nilai Kepatuhan Santri. Tadris, 7(1).

W, S. J. (2015). Psikologi Pendidikan. Jakarta: Prenada Media Grup.

Yafie, A. (1994). Menggagas Fiqhi Sosial dari Sosial Lingkungan Hidup, Asuransi, Hingga Khuwah. Bandung: Mizan.

Zulhimma. (2013). Dinamika Perkembangan Pondok Pesantren di Indonesia. Darul 'Ilmi, 01(02). 